This item was submitted to Loughborough's Research Repository by the author.

Items in Figshare are protected by copyright, with all rights reserved, unless otherwise indicated.

\title{
Travel plans from the developer perspective
}

\section{PLEASE CITE THE PUBLISHED VERSION}

http://dx.doi.org/10.1680/udap.11.00049

\section{PUBLISHER}

(C) ICE Publishing

\section{VERSION}

AM (Accepted Manuscript)

\section{PUBLISHER STATEMENT}

This work is made available according to the conditions of the Creative Commons Attribution-NonCommercialNoDerivatives 4.0 International (CC BY-NC-ND 4.0) licence. Full details of this licence are available at: https://creativecommons.org/licenses/by-nc-nd/4.0/

\section{LICENCE}

CC BY-NC-ND 4.0

\section{REPOSITORY RECORD}

Yeates, Stephen, and Marcus P. Enoch. 2019. "Travel Plans from the Developer Perspective”. figshare. https://hdl.handle.net/2134/16753. 


\section{Travel plans from the developer perspective}

1 Stephen Yeates MSC, MIHT

Principal Engineer, WSP Group, Birmingham, UK
2 Marcus Enoch MSc, PhD, CMILT, FHEA

Senior Lecturer in Transport Studies, Transport Studies Group, School of Civil and Building Engineering, Loughborough University, Leicestershire, UK
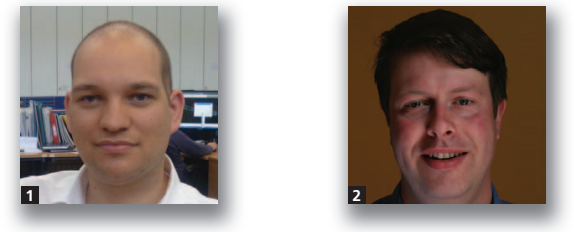

Travel plans are packages of measures tailored to meet the needs of individual sites, which aim to promote greener, cleaner travel choices and reduce reliance on the car. Travel plans deliver transport improvements in a cheap, quick, acceptable and effective way, but to work properly they require institutions such as employers and schools to participate, which they are often unwilling to do voluntarily. Consequently, in the UK travel plans are now often legally required by local authorities through the planning process. This means land developers are major travel plan stakeholders, yet little is known of their views. The aim of this paper is to help redress this by reporting the results of 10 exploratory interviews with informed developers on the topic. The paper highlights that developers are generally positive about travel plans, but have concerns relating to financial penalties and associated future costs. Recommendations are made for practice and policy.

\section{Introduction}

From a practical and political standpoint, transport problems are notoriously difficult for government at all levels to address. This is because transport use is derived from almost every other activity and so is inherently complex. As a consequence, it often requires expensive, time-consuming and/or unpopular measures to be introduced. Yet in the right circumstances, travel plans can be effective at reducing car use, while being politically acceptable and relatively cheap and quick to introduce.

A travel plan is a 'package of measures tailored to meet the needs of individual sites and aimed at promoting greener, cleaner travel choices and reducing reliance on the car' (EEBPP, 2001: p. 1). Travel plans are often introduced by larger companies, hospitals and universities to help staff/ visitors to access a site more easily, address parking problems, reduce on-site traffic congestion, improve the local environment, enhance the image of the organisation, or meet regulatory requirements. Typical measures include providing good quality public transport information, subsidising local public transport services, improving facilities for pedestrians and cyclists, and dissuading people from arriving by car at a site through parking restrictions or charges.
At the site level Cairns et al. (2008) report that 24 workplace travel plans, also known as site-based 'transportation demand management' in the USA or 'company mobility management' in Europe, cut car use by between 10 and $25 \%$, while Hillsman et al. (2001) found an average 6\% reduction at sites in Washington State, and NTA (2010) reported an 18\% reduction in car use from workplace travel plans based on data from Ireland. Meanwhile, the Northamptonshire Transport Strategy for Growth in the UK (NCC, 2007) noted that a combination of good land-use planning and a good travel plan could achieve a modal shift of up to $20 \%$ at residential developments.

Fundamentally, such results are possible because travel plans capitalise on the fact that the implementing organisation (e.g. an employer) potentially exerts a far stronger influence over the individuals travelling to their site (e.g. employees, visitors) than a local authority does over its populace, for example. Unfortunately for government, however, for travel plans to work there is a need to engage such 'implementing organisations' and this has not always proved to be a straightforward process, owing mainly to travel plans being somewhat peripheral to the core mission of most organisations (Enoch, 2012). Thus results at 
the local or regional network level have not been so significant as yet.

Enoch and Potter (2003) identified several ways for government to 'persuade' organisations to participate in travel planning, namely by information/exhortation, regulation, subsidy or through the tax regime. Of these, in the UK case, the favoured approach so far has been to apply a fairly pragmatic regulatory approach, whereby organisations seeking to develop on a new or existing site are required to devise a travel plan in return for obtaining planning permission. As a result, it is now the case that the majority of travel plans in the UK have been adopted through this mechanism (Rye et al., 2011). Yet despite its importance, only a limited amount of research has been conducted in this area, and none at all has been found on the views of developers regarding the travel plan process.

The purpose of this paper, therefore, is to report the results of a MSc project undertaken at Loughborough University, which drew on exploratory in-depth interviews with 10 developers to: identify key characteristics relating to travel plans in the planning process; determine an initial idea of how developers view the concept and role of travel plans in the planning process currently; and propose recommendations for practice and policy.

The following section reviews the relevant literature in the field; section 3 outlines the method used; section 4 describes the findings and section 5 provides the conclusions and implications for policy.

\section{Literature review}

This section reviews existing literature relating to the nature and role of developers, travel plans and their delivery by way of the planning process.

\subsection{The nature and role of the developer}

Travel plans should involve a wide range of stakeholders. These include a range of interests within local authorities (e.g. planning, transport, highways, legal, education and housing departments), developer/occupiers (applicants, developers, site owners, developer occupiers) and interested parties such as the local community and public transport operators (Addison et al., 2009).

However, despite their prominence in the above list and the importance of the planning process in delivering travel plans, developers have been largely ignored as an impact group. Indeed, only Addison et al. (2009) appear to have sought developer opinions, and even then only the largest, national level organisations were consulted. Cairns et al. (2005) ascribed this observation to developers being a difficult group with which to engage.
This is potentially problematic, because developers undertake the majority of land development, not only investing in the land but also deciding on the type, size and densities of development, and the rate at which the land is built on, making them a key driver in land use planning and the spatial formation of urban areas (Robinson and Robinson, 1986).

Developers can be either a private or public sector (e.g. National Health Service) concern. Meanwhile, Alberini et al. (2005) found from a survey of developers on land contamination that some developers sell the final projects, some lease their projects and some retain ownership themselves. Thus, a developer can be defined as being an entrepreneur or a member of a land development firm who invests in and purchases land for development.

In travel planning terms then, under the current UK enforcement regime, the developer takes the role of the mediator of travel plans and the local authority provides the role of the regulator (Rye et al., 2011). Such a distinction is expanded by Cullingworth and Nadin (1997), who noted the following tensions in such a relationship.

A developer's primary concern is to generate profit and income in as short a period as possible, whereas the planning world is concerned with the long-term land uses and spatial form, so developers usually wish to act quickly as they have spotted an opportunity within the market.

- Developers prefer to develop on 'greenfield' (i.e. previously undeveloped) sites where they have a relatively blank canvas, rather than 'brownfield' (previously developed) sites, which can have associated extraneous problems. Planners often require development on brownfield sites in order to revive or regenerate an area.

Developers experience economic pressures and their timing in a market can be critical. Planners experience political pressures and are concerned with their long-term plan rather than market forces.

Clearly, the fundamental stances of developers and planners can lead to conflicts of interest and opposing points of view.

In terms of existing research, on the positive side Cairns et al. (2010) concluded that the best travel plan examples studied demonstrated significant reductions in car use, and that many of these were developed through being a requirement of the planning system. However, there are also a number of problems with such mandatory approaches. Thus, Dill (1998), Rye (2002), Rye et al. (2011) and Roby (2010) suggested that issues include the following.

Monitoring of the mandated travel plans is often inadequate, meaning enforcement is not possible. (This is in spite 
Urban Design and Planning

Volume 166 Issue DP5
Travel plans from the developer

perspective

Yeates and Enoch of monitoring regimes such as TRICS and iTrace now being available for public authorities to use.)

- The ultimate occupier, who is often not known to the developer or involved in the creation of the travel plan as part of the planning process, is not motivated to engage in the process.

The planning system is an imperfect tool to secure travel plans because it does not embed objectives into the organisation's business processes.

Regulation of travel plans through the planning system forces employers to respond to traffic congestion, despite them not necessarily perceiving it as being their problem.

- Travel plan implementation becomes dependent on the level of economic activity, which may result in difficulties in imposing travel plans during a recession.

- Too rigid regulation sees the burden being placed on the employer or developer of the site, which can disengage a stakeholder from the travel plan.

- Regulating travel plans through the planning process will not result in travel plans being implemented where they are most needed but at locations where new development occurs.

De Tomassi et al. (2009) reviewed how land use and mobility management policies are integrated across 10 European Union countries. The MaxLupo study reported that regulatory devices are by far the most common approach, of which one is the current use of the UK planning system for requiring travel plans.

\subsection{Travel plans and the planning process in the UK} In the UK currently national government sets transport and planning policies (see Table 1 for an overview of relevant policy events in this area), which guide local authorities in how to apply these policies at the local level in an appropriate way. In practice, in the UK travel plans can be required in one of two ways.

- Planning obligation/agreement - under section 106 of the Town and Country Planning Act (1990), planning gain agreements can restrict land being used in certain ways or involve developers paying to provide infrastructure or services to connect with the site. These are more flexible than a planning condition but often involve lengthy negotiations. It is suggested that an obligation/agreement would allow more complex travel plans to be secured.

- Planning condition - a condition requires the developer to provide certain measures or infrastructure in advance of the development opening. Conditions may only be attached on the basis that they fulfil a planning condition, are necessary, relate to the development and are not unreasonable.

Rye et al. (2011) provide further details as to how the UK system works in practice.

\subsection{The future of travel plans in the UK context}

With regard to the future, Enoch and Ison (2012) commented that travel plans in the UK have been implemented to varying degrees of success. To address this it is suggested that the government should provide more direction at the strategic level and allocate more resources to improve procedures and ensure that monitoring processes are enhanced. Travel plan objectives should also be linked to other related policies, such as those relating to obesity. In addition, organisations should integrate travel plans with their management strategies and ensure that the travel plan objectives are not marginalised.

To summarise, while evidence exists documenting the perspectives of those organisations with travel plans and those agencies promoting and regulating them, little research has taken the view of the 'specialist' developer into account.

\section{Method}

A series of face-to-face, semi-structured, in-depth, exploratory, qualitative interviews was undertaken with 10 developers, who were chosen following a form of purposive sampling strategy, whereby participants were selected to meet the specific needs of the researcher (Trochim, 2006; Weintraub Austin and Pinkleton, 2006). For this research, the criteria were that

only developers where profit maximisation was the primary motivation were selected (i.e. only individuals or organisations that operate in the private sector)

only developers who are not the final end user or occupier were interviewed; in other words, developers who only sell or lease their developments were included, whereas individuals or organisations involved in developing land for their own occupation, such as supermarket operators, were excluded.

The interviewees were chosen based on contacts of the authors, and all but one had at least 10 years of experience working in the sector (see Table 2 for details of those interviewed).

Table 3 sets out the question prompts that emerged from the literature and details the areas explored in the interviews. In brief, these first examined the role of the developer in travel planning, followed by developer opinions on the travel plan concept, the current 'performance' of travel plans, and the future of travel plans.

The interviews were conducted between March and June 2010. The data were then analysed using thematic analysis, a process that determines commonalities, relationships and differences across a set of different responses (Gibson and Brown, 2009), to gain an initial understanding as to how developers perceive travel plans and to highlight possible recommendations for practitioners and policy makers. 


\begin{tabular}{|c|c|c|c|}
\hline Date & Publisher & Title & Outcomes \\
\hline 1998 & DETR & $\begin{array}{l}\text { A New Deal for Transport: } \\
\text { Better for Everyone }\end{array}$ & $\begin{array}{l}\text { Marked shift in policy, whereby alternatives to road building were considered. } \\
\text { Introduced concepts of integrating transport policy and changing travel } \\
\text { behaviour towards more sustainable modes of travel. }\end{array}$ \\
\hline $\begin{array}{l}2001 \\
\text { (revised in }\end{array}$ & $\begin{array}{l}\text { ODPM } \\
\text { 2011) }\end{array}$ & $\begin{array}{l}\text { Planning Policy Guidance } \\
\text { 13: Transport }\end{array}$ & $\begin{array}{l}\text { Sought to integrate transport and land use policy. Set out that travel plans } \\
\text { should support large-scale planning applications for development. }\end{array}$ \\
\hline 2002 & DfT & $\begin{array}{l}\text { Using the Planning Process } \\
\text { to Secure Travel Plans }\end{array}$ & $\begin{array}{l}\text { Investigated travel plans and provided examples of best practice. Discussed } \\
\text { issues with enforcing travel plans and setting targets. }\end{array}$ \\
\hline 2004 & DfT & $\begin{array}{l}\text { Smarter Choices - } \\
\text { Changing the Way We } \\
\text { Travel }\end{array}$ & $\begin{array}{l}\text { Reviewed evidence on the take-up and effectiveness of travel plans, their } \\
\text { costs, promotion, use of the planning system and effects. }\end{array}$ \\
\hline 2006 & $\begin{array}{l}\text { HM } \\
\text { Treasury }\end{array}$ & Eddington Transport Study & $\begin{array}{l}\text { Recommended action should address areas where congestion is worst, } \\
\text { typically the large urban areas during the a.m. and p.m. commuting periods. } \\
\text { Advocated pricing and regulation instruments to make best use of existing } \\
\text { infrastructure, rather than providing new infrastructure. }\end{array}$ \\
\hline 2007 & DfT & $\begin{array}{l}\text { Guidance on Transport } \\
\text { Assessment }\end{array}$ & $\begin{array}{l}\text { Provides guidance on transport assessment, transport statement and travel } \\
\text { plan processes when submitted as part of a planning application. The } \\
\text { guidance includes thresholds by development type and size, specifying when } \\
\text { each report would be required. }\end{array}$ \\
\hline 2008 & Various & $\begin{array}{l}\text { National Specification for } \\
\text { Workplace Travel Plans } \\
\text { (PAS 500) }\end{array}$ & Aimed to improve the quality and consistency of workplace travel plans. \\
\hline 2009 & DfT & $\begin{array}{l}\text { Delivering Travel Plans } \\
\text { through the Planning } \\
\text { Process }\end{array}$ & $\begin{array}{l}\text { Provides guidelines on the development of travel plans, promotion of } \\
\text { sustainable transport measures and also numerous suggestions and case } \\
\text { studies as to how travel plans can be secured through the planning process. }\end{array}$ \\
\hline
\end{tabular}

Table 1. Land use and transport planning policy/guidance

influencing travel plans in the UK

\section{Findings}

This section focuses first on the role of the developer, followed by developer perspectives on the travel plan concept and its performance, and lastly on the future of travel plans.

\subsection{The role of a developer}

The interviewees defined a developer as being

'an individual or company (interviewee G) that engages in a speculative process (J) to identify sites (D) which offer commercial potential to meet either known or anticipated market demand $(G)$; obtain control of suitable land resources (G) (sites); and bring the sites forward $(\mathrm{H}, \mathrm{J})$ through the land use planning process (D) to change the status of that parcel of land $(\mathrm{C})$, thus uplifting land values (B) and thereby generating commercial benefit (C), i.e. profit (B, G).'

In classifying developer 'types' three categories emerge from the data, namely developers may

manage this process on behalf of a land owner (project manager)

sell or trade the site (D) without necessarily undertaking the actual building process $(\mathrm{H})$ (property trader) hold onto the developed land as an asset (D) (property investor).

The contacts can be categorised into different 'types' of developer as detailed in Table 4.

\subsection{The travel plan concept}

The interviewees were asked to describe how they perceive the concept of a travel plan (see Table 5). The majority of the developers' perceptions of travel plans focused on the influence of public policies. The interviewees commented that a frequent outcome of a travel plan was to increase the use of sustainable modes of travel (A, B, C, E, F, H, J) with some of the developers commenting that the process would often involve setting targets $(\mathrm{F}, \mathrm{H}, \mathrm{J})$.

Analysis of Table 5 also reveals that a significant number of the developers' responses could be grouped as public policy objective types (A, E, F, H, J). However, two of the developers $(D, G)$ did not discuss public policy objective types, but instead discussed mixed/organisation objective types such as reducing costs and meeting targets set out in their business plans. 


$$
\text { Consultant/developer }
$$

B

Local government authority/town planner/ developer

Public sector officer/developer

D

Banking/developer

$E$

Site engineer/construction/developer

Local government authority/consultant/ developer

H

Local government authority/consultant/ developer

\section{Development project manager}

Director of engineering consultant, responsible for team that produces travel plans for wide range of developments. Previously, worked for national residential developer.

Background in town planning with experience in residential development. Has promoted more than 10 developments where travel plans were required, some of which were in London. Has had involvement in travel plans from inception stage onwards.

Qualified as town planner and worked in local authority organisations before moving to work for a developer. Has reviewed travel plans as part of the planning process and promoted developments where travel plans were required.

Worked in banking sector before moving into development. Has taken range of developments through the planning process, which required travel plans.

Promoted a wide range of development types. Has been involved with developments where local authority and/or Highways Agency have required travel plans.

Now works for developers after years working for engineering firms. As a developer, has promoted several projects where travel plans were required. Specialises in promoting developments for tenants.

Has worked as a developer for over 15 years. Had previous experience in local authority planning department and also as a planning consultant. Has been involved in travel plans produced for the planning process and implemented them on behalf of tenants. Worked for local government and then for a planning consultant. Has worked for over 10 years for a development firm promoting residential and commercial sites.

Works for a consultant specialising in managing development projects. Regularly reviews travel plans being submitted with planning applications.

Qualified as chartered surveyor and worked for a development corporation, but now works for a developer. Has promoted travel plans for several commercial developments.

Table 2. Interviewee experience

\subsection{What do travel plans involve?}

Initially, travel plans were not seen as being significant considerations in the land use planning process, and that once produced, the early travel plans were only really providing information on travel alternatives and did not involve any real commitments (A, B, E). However, they report that the level of detail now required has increased significantly in comparison to those early travel plans. Interestingly, two respondents (E, J) suggested that travel plans should probably have remained as information-providing documents or 'travel guides' until the end user is known, and at that point the responsibility of taking the document forward should fall on to the end user or occupier. In other words, they did not feel that addressing transport issues was their problem.
The interviewees were very aware of the content of travel plans and mentioned the importance of site and transport characteristics, the role of objectives, target setting, appropriate measures and the need for ongoing monitoring; however, there are further concerns. Specifically, one interviewee's concern was centred on the cost and deliverability, and he stated that he was reluctant 'to sign up to an open ended cheque' (A). Essentially he felt an ultimate financial cap should be in place.

\subsection{Motivations for undertaking a travel plan}

Perhaps understandably, the primary motivation for developers adopting travel plans for eight of the 10 interviewees (A, B, C, D, $\mathrm{E}, \mathrm{H}, \mathrm{I}, \mathrm{J})$ was to secure planning permission. In addition, 
The interview consisted of four broad sections: personal information, travel plan definitions, travel plan performance, and the future.

Personal information

1. Could you please describe your background?

2. Approximately how many travel plans have you been involved with, and when did you first become involved?

3. Could you estimate how much of your time you spend on travel plans and has this changed over time?

What is a travel plan?

1. From your perspective, how would you define a travel plan?

2. What does the typical travel plan look like in your experience?

3. What are the main motivations for developing a travel plan from a developer perspective?

4. From your perspective, what have the purpose/objectives of travel plans been?

How well do travel plans perform?

1. What general costs and benefits do you perceive, for yourself as a developer, in developing a travel plan? Do the benefits outweigh the costs?

2. What are the main issues and challenges in developing a travel plan for the developer?

3. From your perspective, what good/bad travel plan practices have you experienced?

What does the future hold for travel plans?

1. How are travel plans likely to be developed in the future?

2. How should travel plans be developed in the future?

3. Do travel plans achieve their full potential and are they a good idea?

Table 3. Developer interview prompts

however, four (A, B, D, I) of these mentioned secondary motivations. These were as follows: kudos and the justification to reduce development trip rates on which the site is assessed as part of the planning application; improves accessibility and provides a selling feature; improves accessibility and protects the local community; and contributes to wider sustainability policy. Meanwhile, the other two interviewees (F, G) (both property investors incidentally, maybe taking the longer term view) cited corporate social responsibility and accessibility planning as being the primary drivers of the travel plans.

\subsection{The benefits and costs of travel plans}

Table 6 sets out the benefits and costs of travel plans as perceived by the interviewees. Overall, the majority of respondents felt that travel plans were a positive item that helped to produce a better, more sustainable development and ultimately helped them obtain planning permission. However, two respondents $(E, J)$ felt that the costs exceeded the benefits, primarily because they saw little or no benefit in producing a travel plan.

\subsection{The developers' perspective of the issues and challenges}

When asked about the issues and challenges facing developers, one of the recurring themes was of the long-term responsibility for the travel plan and its measures (A, B, F, G, J). The ownership of a travel plan in the long term is a difficult issue, particularly when financial conditions are involved in regard to monitoring. In particular, the property traders, who can have a relatively short ownership of a site, were nervous when

\begin{tabular}{|c|c|c|c|c|}
\hline \multirow[b]{2}{*}{ Land use } & & \multicolumn{3}{|c|}{ Developer type } \\
\hline & & Project manager & Property trader & Property investor \\
\hline \multirow[t]{4}{*}{ Development form } & Commercial & & J & $\mathrm{F}$ \\
\hline & Residential & & B & \\
\hline & Mixed land uses & & $A, C$ & \\
\hline & Varied & I & $D, E, H$ & G \\
\hline
\end{tabular}




\begin{tabular}{|c|c|c|c|c|c|c|c|c|c|c|c|c|}
\hline \multirow{3}{*}{$\begin{array}{l}\text { Sources of } \\
\text { motivation } \\
\text { process }\end{array}$} & \multicolumn{2}{|c|}{ Objective type } & \multicolumn{10}{|c|}{ Developer type } \\
\hline & \multirow{2}{*}{ Related } & \multirow{2}{*}{ Outcome related } & $\begin{array}{l}\text { Project } \\
\text { manager }\end{array}$ & \multicolumn{7}{|c|}{ Property trader } & \multicolumn{2}{|c|}{$\begin{array}{l}\text { Property } \\
\text { investor }\end{array}$} \\
\hline & & & 1 & A & B & C & D & E & H & J & $\mathrm{F}$ & G \\
\hline \multirow[t]{4}{*}{ Public policy } & Targets & & & & & & & & $\checkmark$ & $\checkmark$ & $\checkmark$ & \\
\hline & & $\begin{array}{l}\text { Reduction in single- } \\
\text { occupancy vehicles }\end{array}$ & & $\checkmark$ & $\checkmark$ & & & & & $\checkmark$ & & \\
\hline & & $\begin{array}{l}\text { Reduction in } \\
\text { congestion }\end{array}$ & $\checkmark$ & & & & & $\checkmark$ & & & & \\
\hline & & $\begin{array}{l}\text { Increase use of } \\
\text { sustainable modes } \\
\text { of travel }\end{array}$ & & $\checkmark$ & $\checkmark$ & $\checkmark$ & & $\checkmark$ & $\checkmark$ & $\checkmark$ & $\checkmark$ & \\
\hline \multirow[t]{4}{*}{ Mixed } & $\begin{array}{l}\text { Managing } \\
\text { impacts }\end{array}$ & & & & & $\checkmark$ & $\checkmark$ & & & & & \\
\hline & $\begin{array}{l}\text { Managing } \\
\text { travel }\end{array}$ & & & & & & & & & & & $\checkmark$ \\
\hline & & The green agenda & & & & & $\checkmark$ & & & & & \\
\hline & & Sustainable access & & & & & $\checkmark$ & & & & & \\
\hline \multirow[t]{3}{*}{ Organisation } & Costs & & & & & & $\checkmark$ & & & & & \\
\hline & $\begin{array}{l}\text { Business } \\
\text { plan }\end{array}$ & & & & $\checkmark$ & & & & & & & $\checkmark$ \\
\hline & $\begin{array}{l}\text { Benefits to } \\
\text { staff }\end{array}$ & & $\checkmark$ & & & & & & & & & \\
\hline
\end{tabular}

Table 5. Developer perspectives of travel plans

conditions required them to take ownership of a travel plan in the longer term. Related to this is the question as to whether measures that require subsidy, such as buses, will be viable in the future. One of the respondents $(\mathrm{G})$ felt that the balance was not correct, that a developer's role should be to provide infrastructure, set up measures and implement initiatives rather than there being an expectation that they be involved at the site indefinitely.

A number of the respondents (A, E, G, H, J) mentioned that, in their opinion, travel plans require both incentives to use sustainable modes of travel and deterrents to using the car. In particular, a respondent $(G)$ felt that government needed to provide stronger deterrents in the form of road-user charging and/or workplace parking levies. Notwithstanding, one respondent $(\mathrm{H})$ stated that parking restrictions at residential developments negatively impacted on the values of the properties. In summary, the interviewees felt that developers should provide sustainable travel incentives, while the government should facilitate the deterrents to car travel.

Lastly, there was a view expressed by three interviewees (E, G, $\mathrm{J})$ that a particular issue or challenge occurred when a development was speculative and the end user was unknown.
In this case the developer is making decisions about an unknown business; therefore, they will naturally seek a travel plan that has the least onerous conditions possible so as to ensure the saleability of their development.

\subsection{How will the travel plan be developed in the future?}

For the future, the interviewees were asked how they expected travel plans to develop and how they thought travel plans should be developed; the results are presented in Table 7, from which several interesting observations emerge. First, there is a feeling that travel plans should be more targeted at the end user than the developer and that the measures implemented by developers should comprise primarily infrastructure and informational initiatives.

Second, the importance of developing stronger relationships was mentioned so that measures that are 'reasonable' for the site can be negotiated rather than imposed, while monitoring was expected to be made more comprehensive (although it was stated that this ought not to be the responsibility of the developer or the occupier). The interviewees also suggested that they would respond more to fiscal incentives through subsidy and tax breaks rather than legal penalties. 


\begin{tabular}{|c|c|c|c|c|c|c|c|c|c|c|c|}
\hline & & \multicolumn{10}{|c|}{ Developer type } \\
\hline & & \multirow{2}{*}{$\begin{array}{c}\begin{array}{c}\text { Project } \\
\text { manager }\end{array} \\
\text { I }\end{array}$} & \multicolumn{7}{|c|}{ Property trader } & \multicolumn{2}{|c|}{$\begin{array}{l}\text { Property } \\
\text { investor }\end{array}$} \\
\hline & & & A & $\mathrm{B}$ & $\mathrm{C}$ & $\mathrm{D}$ & $E$ & $\mathrm{H}$ & J & $\mathrm{F}$ & G \\
\hline \multirow[t]{6}{*}{ Benefits } & Obtaining planning permission & $\checkmark$ & $\checkmark$ & & & & & & & $\checkmark$ & \\
\hline & Reducing the cost of highway works & & $\checkmark$ & & & & & & & $\checkmark$ & \\
\hline & Increasing the quantum of development & & & & & & & & & $\checkmark$ & \\
\hline & Corporate social responsibility & & & & $\checkmark$ & & & & & $\checkmark$ & \\
\hline & $\begin{array}{l}\text { Producing a quality development, } \\
\text { adding value }\end{array}$ & $\checkmark$ & & & & $\checkmark$ & $\checkmark$ & $\checkmark$ & & & \\
\hline & No benefit to developer & & & & & & $\checkmark$ & & $\checkmark$ & & \\
\hline \multirow[t]{4}{*}{ Costs } & The coordinator & & $\checkmark$ & & & & $\checkmark$ & $\checkmark$ & & $\checkmark$ & $\checkmark$ \\
\hline & The sustainable initiatives and measures & & $\checkmark$ & & $\checkmark$ & & & $\checkmark$ & & & \\
\hline & Monitoring and financial commitments & & & $\checkmark$ & & $\checkmark$ & & $\checkmark$ & $\checkmark$ & $\checkmark$ & \\
\hline & Preparation costs & & $\checkmark$ & $\checkmark$ & $\checkmark$ & & $\checkmark$ & & & & \\
\hline
\end{tabular}

Table 6. Developer perspectives of travel plan benefits and costs

Third, travel plans should be focused more on organisational needs than currently - hence the idea of travel plan measures being a part of a 'benefits package' and the call for less onerous data collection processes. In addition, it was felt that travel plans are here to stay because they are being integrated into local transport and planning processes and that this was generally a positive action, although in an ideal world the transport system would be designed in such a way as to render them redundant.

\subsection{Are travel plans a good idea and do they achieve their full potential?}

This addressed the concluding question of the section on the future of travel plans. Nine of the 10 interviewees responded that travel plans are a good idea but did not achieve their full potential. While the other respondent (E) suggested that they were not a good idea and said that they were only setting out 'common sense'.

As to the reasons why travel plans do not achieve their full potential, the interviewees (A, I) indicated that they were dubious as to how many schemes are still operated in the long term and that there were issues in occupiers picking up the travel plan and buying into the requirements set out in the document (E, G). It was also noted (B) that there was insufficient evidence on the typical modal shift achieved by a travel plan once in operation. It was commented that, owing to the nature of travel plans and sustainable travel, there is always more one can do (F) and therefore by its very nature a travel plan cannot achieve its full potential. Lastly, it was stated that travel plans need a series of indirect supporting measures or policies that will constrain car use (A), or increase the cost of car use, to make the sustainable modes more attractive.

\section{Discussion}

This section now compares the findings gained from the interviews with those of the literature review.

\subsection{Nature of a developer}

The findings suggest that a developer engages in an often speculative process that is commercially motivated, whereby the status of a parcel of land is changed through the planning process and thus the value of that land is increased. Essentially, three types of developer emerge, namely project manager, property trader and property investor.

This understanding closely matches the definitions found in the literature (e.g. Alberini et al., 2005; Cullingworth and Nadin, 1997; Robinson and Robinson, 1986; Rye et al., 2011). One other key point, which was only implicitly raised in the interviews, related to the tensions between developers and local authority planners in agreeing responsibilities for undertaking travel planning actions (Cairns et al., 2005).

\subsection{The travel plan product}

The majority of interviewees perceived the travel plan to be focused on public policy objectives, particularly on increasing the use of sustainable modes of travel. They also reported that although, initially, travel plans were not seen as being very 


\begin{tabular}{|c|c|c|c|}
\hline Groups & Themes & Expected development & Ideal development \\
\hline $\begin{array}{l}\text { What is a travel } \\
\text { plan? }\end{array}$ & The form of a travel plan & $\begin{array}{l}\text { More emphasis on commercial } \\
\text { uses (E) }\end{array}$ & $\begin{array}{l}\text { Emphasis should be placed on end } \\
\text { user rather than developer (E) } \\
\text { They should be a travel guide (I) }\end{array}$ \\
\hline \multirow[t]{3}{*}{$\begin{array}{l}\text { Travel plan } \\
\text { performance }\end{array}$} & Stakeholders and partnerships & $\begin{array}{l}\text { Increased use of area travel } \\
\text { plans (F) }\end{array}$ & $\begin{array}{l}\text { Build relationships between the } \\
\text { stakeholders }(F) \\
\text { More cooperative }(G)\end{array}$ \\
\hline & Monitoring & $\begin{array}{l}\text { There will be increased } \\
\text { monitoring }(A, B)\end{array}$ & $\begin{array}{l}\text { Local authorities should be } \\
\text { required to monitor them }(C)\end{array}$ \\
\hline & Motivation & $\begin{array}{l}\text { Increased use of financial } \\
\text { penalties }(A, J)\end{array}$ & $\begin{array}{l}\text { They would be more successful if } \\
\text { cost savings were involved }(A, F)\end{array}$ \\
\hline \multirow[t]{4}{*}{$\begin{array}{l}\text { The future of } \\
\text { travel plans }\end{array}$} & Promotion & & $\begin{array}{l}\text { Should be sold to staff at sites as } \\
\text { part of a benefits package (F) } \\
\text { They should involve fewer data and } \\
\text { statistics (I) }\end{array}$ \\
\hline & Continued use & $\begin{array}{l}\text { Here to stay and continued } \\
\text { pressure to sign up }(A, H) \\
\text { Integrated in policy and } \\
\text { planning process }(B, C) \\
\text { Important role in } \\
\text { managing congestion and } \\
\text { reducing volumes of traffic }(\mathrm{I}, \mathrm{H})\end{array}$ & $\begin{array}{l}\text { They should be maintained in the } \\
\text { process }(A, C) \\
\text { Highway authorities should retrofit } \\
\text { older travel plans }(F)\end{array}$ \\
\hline & Supporting measures & & $\begin{array}{l}\text { Local authorities need to promote } \\
\text { travel plans through adequate } \\
\text { sustainable transport infrastructure } \\
\text { and policy constraints on the car } \\
(\mathrm{A}, \mathrm{I})\end{array}$ \\
\hline & Not required & & $\begin{array}{l}\text { If infrastructure and constraints are } \\
\text { in place then travel plans are not } \\
\text { required as not using a car } \\
\text { becomes the logical choice }(A, E)\end{array}$ \\
\hline
\end{tabular}

Table 7. Developer perspectives of the future of travel plans

important, this was now changing. From a developer's perspective this increased role was seen as being problematic, especially when the end user is not known at the time planning permission is sought. Instead the interviewees felt that that travel plans should have remained more an information measure. Additionally, interviewee concerns centred on the high cost associated with travel plan measures, which in some cases could potentially continue indefinitely. Unsurprisingly, securing planning permission is the primary motivation for developers adopting travel plans, although secondary motivations such as improving site access were sometimes mentioned.

Here the literature indicates the increasing importance of the planning system in delivering travel plans in the UK, across Europe and also in the USA (Dill, 1998), and the fact that these mechanisms tend to be driven by public policy goals.
Roby (2010) meanwhile suggests the findings regarding travel plan motivations match those of organisations more generally in adopting travel plans. Interestingly, the concerns about high costs and uncertainty raised in the interviews do not appear to have been mentioned in the existing literature.

\subsection{Travel plan performance}

On balance, travel plans were perceived to be a benefit, although this view was not universal. Regarding issues and challenges facing travel plans, sorting out the long-term management, financing and ownership was seen to be crucial, particularly to property traders, while government support for constraining car use was seen as being necessary if a travel plan was to be effective.

On travel plan performance, the consensus in the literature sees travel plans imposed through 'too rigid' regulation as being a 
burden on organisations, particularly when no attempt is made to integrate them into existing organisational processes, while there is a fear expressed that travel plans are not always implemented at the most appropriate sites (Enoch, 2012; Rye, 2002).

\subsection{The future of travel plans}

Overall, travel plans were felt to be a good idea by all but one interviewee, but none felt they had achieved their full potential. This was thought to be attributable to: ignorance about the potential effects of a travel plan; responsibility for the travel plan passing from the developer to the site occupier, who may not subscribe to the measures proposed; the lack of monitoring generally applied by local authorities; and a perceived lack of wider policy support from local authorities.

The reviewed literature identified that greater support is required from the government in order to ensure that travel plans are successfully implemented (Enoch and Ison, 2012; Enoch and Potter, 2003). In line with those comments made during the interviews, it is perceived that governments at all levels are not providing sufficient support in terms of resources and supporting policies.

\section{Conclusions and implications for policy and practice}

The aim of this research was to explore travel plans from the perspective of a key stakeholder - the developer. In achieving this aim, the authors have sought to: identify key characteristics relating to travel plans in the planning process; determine an initial idea of how developers view the concept and role of travel plans in the planning process currently; and to propose recommendations for practice and policy.

In light of the literature review it emerged that the planning process can be an important mechanism for introducing travel plans, yet the views of developers towards travel plans have been under-represented in research exercises to date (Addison et al., 2009; Cairns et al., 2005). Essentially, the key issues are that travel plans are seen as being a burden rather than a positive process by developers, while the focus on new sites means that travel plans are not always delivered where most needed. Moreover, developers are often only involved at a site for a short period of time and so perhaps are not best placed to ensure the long-term success of travel plans.

Next, the core findings from the interviews suggested the following.

- Developers had a good understanding of travel plans and what they generally involved. However, many of the responses discussed carbon reduction and omitted mentioning reducing traffic congestion as being important.
- Major concerns related to financial penalties and the associated future costs that travel plans can tie developers into.

The main benefits identified by the developers were centred on the cost savings that travel plans could provide to them and the site occupiers.

There were concerns among developers regarding practices whereby they were required to introduce travel plan measures supposedly sufficient to achieve a set level of modal shift, but yet still have to provide highway infrastructure improvements seemingly based on the assumption that the travel plan would have no effect on traffic levels.

Drawing these together, using the planning process to speed up the introduction of travel plans and their associated benefits has certainly worked to some degree, at least in the UK, and in jurisdictions where local planning authorities are empowered to 'persuade' developers to engage with the process there would seem to be some scope to apply this approach more broadly.

In terms of recommendations for practice and policy, ultimately, there is an argument that developments sited in the optimum locations from a transport perspective might perhaps negate the need for a travel plan because the existing/ proposed transport system would be sufficient to meet the newly generated demand. However, travel plans can be an appropriate treatment in the (frequent) situations where this is not the case. In these circumstances

future policies ought to consider better the nature of a developer and their level of involvement at a site

travel plan partnerships should be developed among the various stakeholder groups to ensure that all are actively involved and buy into the objectives of the travel plan

there is still a need for further evidence on the benefits of travel plans (which suggests that monitoring efforts using packages such as TRICS and iTrace to capture transport impacts, together with other mechanisms for assessing broader economic, social and environmental effects, need to be improved)

supporting policies that constrain car use and improve alternative modes are ultimately required in order for travel plans to achieve their full potential.

Finally, it needs to be recognised that although conducting indepth interviews with a relatively small number of wellinformed practitioners is an appropriate methodology for identifying issues in this area, on their own these interviews are not sufficient to provide more than a tentative indication about how the developer sector perceives the travel plan. In this regard, a far broader survey of such opinions would be needed, which could of course be based on this initial study. Moreover, 
Urban Design and Planning

Volume 166 Issue DP5
Travel plans from the developer

perspective

Yeates and Enoch it should also be recognised that this policy area continues to develop apace, and that consequently it has not been possible to incorporate changes in the wider context that have occurred subsequently (or indeed might change in the future). Thus, for example, changes to the national planning policy framework, the widespread adoption of the community infrastructure levy, or shifts in policy emphasis towards localism and deregulation in the planning system, could potentially transform how travel plans are used and perceived by developers, but anticipating how exactly would not be an easy task.

In conclusion, it is clear from the research that considering the perspectives of this key stakeholder as part of the development of future policy and guidance is vital if travel plans are to achieve their full potential. It is also evident that there are many issues to overcome with regard to the marriage of travel plans and regulation through the planning process, and that these relate particularly to the non-engagement with developers' views. However, without the buy-in from this key stakeholder then these issues could become obstructive to the future development of travel plans.

\section{Acknowledgements}

The authors would like to offer their sincere thanks to those interviewed and to the WSP Group.

\section{REFERENCES}

Addison L, Holden S, Addison A, Webber S and Newson C (2009) Good Practice Guidelines: Delivering Travel Plans through the Planning Process. Department for Transport (GB) and the Department for Communities and Local Government (GB), London, UK, Summary and Research Report.

Alberini A, Longo A, Tonin S, Trombetta F and Turvani M (2005) The role of liability, regulation and economic incentives in brownfield remediation and redevelopment: evidence from surveys of developers. Regional Science and Urban Economics 35(4): 327-351

BSI (2008) PAS 500:2008: National specification for workplace travel plans. BSI, London, UK.

Cairns S, Sloman L, Newson C et al. (2005) Making Smarter Choices Work. Department for Transport (GB), London, UK.

Cairns S, Sloman L, Newson C et al. (2008) Smarter choices: assessing the potential to achieve traffic reduction using 'soft measures'. Transport Reviews 28(5): 593-618.

Cairns S, Newson C and Davis A (2010) Understanding successful workplace travel initiatives in the UK. Transportation Research Part A 44(7): 473-494.

Cullingworth JB and Nadin V (1997) Town and Country Planning in the UK, 12th edn. Routledge, London, UK.

De Tommasi R, Welsch J, Rye T and Plvnik A (2009) MaxLupo Guidelines for the Integration of Mobility Management with
Land Use Planning. MAX Project, European Commission, Brussels, Belgium, Work Package D Report.

DETR (Department for the Environment, Transport and the Regions) (1998) A New Deal for Transport: Better for Everyone. DETR, London, UK.

DfT (Department for Transport) (2002) Using the Planning Process to Secure Travel Plans. DfT, London, UK.

DfT (2004) Smarter Choices: Changing the Way we Travel. DfT, London, UK.

DfT (2007) Guidance on Transport Assessment. DfT, London, UK. DfT (2009) Delivering Travel Plans through the Planning Process. DfT, London, UK.

Dill J (1998) Mandatory employer-based trip reduction. Transportation Research Record, 1618: 103-110.

EEBPP (Energy Efficiency Best Practice Programme) (2001) A

Travel Plan Resource Pack for Employers. The Stationery Office, London, UK.

Enoch MP (2012) Sustainable Transport, Mobility Management and Travel Plans. Ashgate, Farnham, Surrey, UK.

Enoch MP and Ison SG (2013) Expert perspectives on the past, present and future of travel plans in the UK. Proceedings of the Institution of Civil Engineers - Urban Design and Planning, in press.

Enoch MP and Potter S (2003) Encouraging the commercial sector to help employees to change their travel behaviour. Transport Policy 10(1): 51-58.

Gibson WJ and Brown A (2009) Working with Qualitative Data. Sage Publications, London, UK.

Hillsman EL, Reeves P and Blain L (2001) Estimation of Washington State's trip-reduction programme on traffic volumes and delays: Central Puget Sound Region. Transportation Research Record 1765: 16-19.

HM Treasury (2006) The Eddington Transport Study. Her Majesty's Stationery Office, London, UK.

NCC (Northamptonshire County Council) (2007) Transport Strategy for Growth - Guidance on Creating Lasting Modal Shift. Northamptonshire County Council, Northampton, UK, see http://www.northamptonshire.gov.uk/ (accessed 31/05/2011).

NTA (National Transport Authority, Republic of Ireland) (2010) Smarter Travel Workplaces. NTA, Dublin, Ireland, see http:// www.smartertravelworkplaces.ie (accessed 06/12/2010).

ODPM (Office of the Deputy Prime Minister) (2001) Planning Policy Guidance Notes 13 - Transport. ODPM, London, UK.

Robinson VB and Robinson LC (1986) Dimensions of residential developer. Decision making in a rapidly urbanising region. Socio-Economic Planning Sciences 20(1): 57-60.

Roby H (2010) Workplace travel plans: past, present and future. Journal of Transport Geography 18(1): 23-30.

Rye T (2002) Travel plans: do they work? Transport Policy 9(4): 287-298.

Rye T, Green C, Young E and Ison SG (2011) Using the land-use planning process to secure travel plans: an assessment of 
progress in England to date. Journal of Transport

Geography 19(2): 235-243.

Town and Country Planning Act 1990 (1990) Elizabeth II. Chapter 8. Her Majesty's Stationery Office, London, UK. Trochim WMK (2006) Research Methods Knowledge Base - NonProbability Sampling. Web Center for Social Research, see http://www.socialresearchmethods.net/kb/sampnon.htm (accessed 08/07/2010).

Weintraub Austin E and Pinkleton BE (2006) Strategic Public Relations Management: Planning and Managing Effective Communication Program, 2nd edn. Lawrence Erlbaum Associates, Mahwah, New Jersey, USA.

\section{WHAT DO YOU THINK?}

To discuss this paper, please email up to 500 words to the editor at journals@ice.org.uk. Your contribution will be forwarded to the author(s) for a reply and, if considered appropriate by the editorial panel, will be published as discussion in a future issue of the journal.

Proceedings journals rely entirely on contributions sent in by civil engineering professionals, academics and students. Papers should be 2000-5000 words long (briefing papers should be 1000-2000 words long), with adequate illustrations and references. You can submit your paper online via www.icevirtuallibrary.com/content/journals, where you will also find detailed author guidelines. 